\title{
Workplace violence types in family health, offenders, reactions, and problems experienced
}

\author{
Tipos de violência no trabalho em saúde da família, agressores, reações e problemas vivenciados \\ Tipos de violencia en trabajos de salud familiar, agresores, reacciones y problemas experimentados
}

Isabel Cristina Saboia Sturbelle '
ORCID: 0000-0003-1187-7273

Daiane Dal Pai "

ORCID: 0000-0002-6761-0415

Juliana Petri Tavares" ORCID: 0000-0003-4121-645X

Letícia de Lima Trindade "'I ORCID: 0000-0002-7119-0230

Carmem Lúcia Colomé Beck iv ORCID: 0000-0001-9060-1923

Vittória Zarpelão de Matos" ORCID: 0000-0002-9539-1651

'Universidade Tiradentes. Aracaju, Sergipe, Brazil. "Universidade Federal do Rio Grande do Sul. Porto Alegre, Rio Grande do Sul, Brazil.

'"Universidade do Estado de Santa Catarina. Chapecó, Santa Catarina, Brazil.

"Universidade Federal de Santa Maria. Santa Maria Rio Grande do Sul, Brazil.

How to cite this article: Sturbelle ICS, Dal Pai D, Tavares JP, Trindade LL, Beck CLC, Matos VZ. Workplace violence types in family health, offenders, reactions, and problems experienced.

Rev Bras Enferm. 2020;73(Sppl 1):e20190055. doi: http://dx.doi.org/10.1590/0034-7167-2019-0055

Corresponding author: Isabel Cristina Saboia Sturbelle E-mail: saboia.isabel@gmail.com

EDITOR IN CHIEF: Dulce Barbosa ASSOCIATE EDITOR: Alexandre Balsanelli

\section{ABSTRACT}

Objective: to identify the types of violence that affect the health team in Family Health Units, their offenders, reactions and problems experienced by workers. Method: a cross-sectional, concurrent mixed-type research. The Survey Questionnaire Workplace Violence in the Health Sector was applied to 106 workers from Family Health Units. Of these, 18 answered the semi-structured interview. Results: verbal aggression (65.1\%), bullying (14.2\%), racial discrimination (10.4\%), physical assault (8.5\%) and sexual harassment (4.7\%) were prevalent. Patients were the main perpetrators of verbal aggression (79.4\%) and bullying (46.7\%). Workers responded by telling co-workers and reporting to the boss. Victims remained overalert, vigilant and tense, relating exposure to violence to absenteeism and the desire to leave the profession. Conclusion: verbal aggression is the most common violence with negative impact on workers' health and work performed.

Descriptors: Primary Health Care; Family Health; Workplace Violence; Occupational Health; Nursing.

\section{RESUMO}

Objetivo: identificar os tipos de violência que acometem a equipe de saúde em unidades de Saúde da Família, seus agressores, as reações e os problemas vivenciados pelos trabalhadores. Método: pesquisa transversal, de abordagem mista do tipo concomitante. Aplicou-se o Survey Questionnaire Workplace Violence in the Health Sector em 106 trabalhadores de Unidades de Saúde da Família. Desses, 18 responderam a entrevista semiestruturada. Resultados: foram prevalentes agressões verbais $(65,1 \%)$, assédio moral $(14,2 \%)$, discriminação racial $(10,4 \%)$, violência física $(8,5 \%)$ e assédio sexual $(4,7 \%)$. Os pacientes foram os principais perpetradores das agressões verbais $(79,4 \%)$ e da chefia do assédio moral $(46,7 \%)$. Os trabalhadores reagiram contando para colegas e relatando ao chefe. As vítimas permaneceram superalertas, vigilantes e tensas, relacionando a exposição à violência ao absenteísmo e ao desejo de abandonar a profissão. Conclusão: a agressão verbal é a violência mais comum, com impacto negativo sobre a saúde dos trabalhadores e o trabalho desenvolvido.

Descritores: Atenção Primária à Saúde; Saúde da Família; Violência no Trabalho; Saúde do Trabalhador; Enfermagem.

\section{RESUMEN}

Objetivo: identificar los tipos de violencia que afectan al equipo de salud en las Unidades de Salud de la Familia, sus agresores, las reacciones y problemas experimentados por los trabajadores. Método: investigación transversal de enfoque mixto del tipo concomitante. El Survey Questionnaire Workplace Violence in the Health Sector se aplicó a 106 trabajadores de las unidades de salud familiar. De estos, 18 respondieron la entrevista semiestructurada. Resultados: el abuso verbal (65.1\%), la intimidación (14.2\%), la discriminación racial (10.4\%), la violencia física (8.5\%) y el acoso sexual fueron frecuentes $(4,7 \%)$. Los pacientes fueron los principales autores de la agresión verbal $(79,4 \%$ y y la intimidación (46,7\%). Los trabajadores respondieron contándoles a sus colegas e informando al jefe. Las víctimas permanecieron demasiado alertas, vigilantes y tensas, relacionando la exposición a la violencia con el ausentismo y el deseo de abandonar la profesión. Conclusión: la agresión verbal es la violencia más común con un impacto negativo en la salud y el trabajo de los trabajadores. Descriptores: Atención Primaria de Salud; Salud de la Familia; Violencia Laboral; Salud Laboral; Enfermería. 


\section{INTRODUCTION}

Family Health Units (FHU) work is focused on providing health promotion and prevention services to the population, centered on their needs. As important tools for teamwork organization, as well as building the bond with the community, are listening, dialogue and embracement. These factors help achieve the results of care desired by this model of care, but also ensure recognition and freedom of expression to professionals ${ }^{(1-2)}$.

Studies ${ }^{(3-5)}$ have pointed out that many encounters produced in FHU spaces are permeated by adversities that compromise the quality of care. Users do not always find the resolution they are looking for, often having their expectations of access to services frustrated. The health team is not always given the appropriate condition to provide health care with the desired quality. These circumstances impact on conflicts and disrespect ${ }^{(6)}$, which are potential generators of workplace violence at FHU.

Workplace violence and occupational health have been a concern on the international setting ${ }^{(7-8)}$. It can be practiced in different ways, with physical assault being more easily seen due to the use of physical force and sometimes difficult to assimilate psychological violence, since it intentionally uses the power. Threats, humiliations and embarrassments may be less visible. Psychological violence can be verbal aggression (words that disrespect and degrade dignity); bullying (repeated behavior that disqualifies or demoralizes the person or group); sexual harassment (offensive behavior of a sexual nature) or racial discrimination (offensive or threatening conduct based on race, color, language, nationality, religion or association with a minority) ${ }^{(9-10)}$.

Few studies have addressed violence at Primary Health Care (PHC) services at the international ${ }^{(5,11-13)}$ and national(14-15) levels. They indicate concern about worker exposure and the implications for daily work. In addition to the relevance of the theme to the field of practice, as pointed out by the aforementioned studies, gaps in scientific production on the subject justify the study, especially considering the use of mixed methods. Workplace violence is a phenomenon that has dimensions of interest that can be measured and understood in order to grasp reality more broadly. This research starts from the hypothesis/assumption that family health team professionals are exposed to workplace violence, originated in relationships with users and multidisciplinary team, which imply their health.

\section{OBJECTIVE}

To identify the types of violence that affect the health team in Family Health Units, their offenders, reactions and problems experienced by workers.

\section{METHOD}

\section{Ethical aspects}

The study was previously approved by the Research Ethics Committee of the proposing institution and co-participant institution. The ethical prerogatives of research with human beings contained in Resolution 466/12 of the Brazilian National Health
Board (Conselho Nacional de Saúde) were respected. Participants signed the Free and Informed Consent Term.

\section{Study design}

An observational, mixed approach, concomitant study was developed, and the quantitative cross-sectional phase was carried out simultaneously with the exploratory-descriptive qualitative phase. Strobe guidelines were followed.

\section{Period and place of study}

Data collection took place from June to October 2017. The study setting consisted of the territory used as a field of curricular practices of Universidade Federal do Rio Grande do Sul's PHC, where workplace violence was calling attention of students, professors and workers. This is the area that covers $17 \mathrm{FHU}$ from a health district in the city of Porto Alegre, state of Rio Grande do Sul, southern Brazil. There are assisted over 148,000 inhabitants.

\section{Study population}

All medical professionals, nurses, nursing technicians/assistants and Community Health Agents (CHA) were invited to participate in the study $(n=190)$. Workers who had worked at FHU for at least 12 months were included. Exclusion criteria consisted of working time of less than 12 months on site $(n=36)$, time off during data collection $(n=22)$ and vacation $(n=7)$. In addition, 11 workers who refused to participate in the study and eight who were not accessed because they worked at FHU. It was being targeted by traffickers during the data collection period, which prevented the researcher from entering the territory. The final sample of the quantitative step was 106 workers, which was statistically significant, considering 95\% confidence and 5\% error, 50\% prevalence, calculated with the help of WINPEPI version 11.32. In the qualitative stage, 18 workers from the previous sample participated and were intentionally selected for responding positively to the experience of violence and being sensitive and available to discuss the theme. It was also considered the criterion of data saturation to define the total number of workers interviewed.

\section{Study protocol}

Data collection occurred in two steps. The first was the application of the Survey Questionnaire Workplace Violence in the Health Sector, proposed by the World Health Organization, the International Labor and Public Services Organization and the International Council of Nursing ${ }^{(16)}$. This questionnaire was translated and adapted into Brazilian Portuguese ${ }^{(9)}$. It has been used in Brazilian research ${ }^{(17-19)}$ to identify the occurrence of physical assault, verbal aggression, bullying, sexual harassment and racial discrimination in the workplace in the last 12 months. For each type of violence, offenders, the victim's reactions and the problems experienced were questioned. Along with the mentioned tool, sociodemographic and labor variables were measured in order to characterize workers (sex, age, color, possessing a partner, 
tobacco use, chronic diseases, medication use, average hours of sleep, category, length of experience in the health area and at FHU, to be bosses and employed).

During tool application, a subsample responded to a semistructured interview script that urged to discuss the experience of exposure to violence, including the characterization of the circumstance, the offender, the reactions and problems experienced. Participants' responses were recorded in audio and later transcribed.

\section{Data analysis, and statistics}

For the analysis of quantitative data, descriptive statistics was used with the aid of the Statistical Package for the Social Sciences (SPSS), version 18.0. Categorical (qualitative) variables were described by relative and absolute frequencies. Quantitative variables (continuous and scalar) were described with measures of central tendency and dispersion.

Data from interview transcripts were subjected to thematic analysis ${ }^{(20)}$, originating the categories and their subcategories: Workplace Violence at FHU (Experienced Situations and Perpetrators of Violence); and Reactions and Problems Experienced (Reactions to situations of violence, Problems experienced after episode (s), Consequences and trivialization of situations). To guarantee participant anonymity, speeches were identified by the acronym "INT" of interviewee, following the order of interviews. After statistical analysis of the numerical data and categorization of interviews, the findings were confronted and articulated in order to offer a mixed analysis in response to the objective.

\section{RESULTS}

The sample $(n=106)$ was predominantly female $(80.2 \%)$, with a median age of 42.5 years (34.7 - 51), white (61.9\%), married or with partners $(53,8 \%)$, non-smokers $(85.8 \%)$, with chronic diseases (54.7\%) and on medication (67.9\%). Of these people, $19.4 \%$ used psychotropic drugs and $43.1 \%$ more than one drug class. Professionals reported sleeping on average $6.5(+1.1)$ hours per day. $\mathrm{CHA}$ represented $52.8 \%$ of the sample, followed by nursing technicians/assistants (23.6\%), nurses (15.1\%) and physicians (8.5\%). The experience of health workers was median of 11 years (6-16) and four years of experience at the FHU (3 - 12.2).

Regarding work characteristics, 14 (13.2\%) professionals reported holding positions of bosses/coordinators. Almost all respondents had a CLT-type (The Consolidation of Labor Laws (Portuguese: Consolidação das Leis do Trabalho, CLT) is the decree which governs labor relations in Brazil) employment regimen $(n=102 ; 96.2 \%)$; the others make up the program team plus physicians; and 13 (12.3\%) professionals had another job.

Regarding the violence suffered by FHU workers, Figure 1 presents the percentages found according to the types of violence.

Given the image, it should be added that some participants reported episodes of verbal aggression with strong threats of physical assault and racial discrimination.

[...] I had to call the guard, because that day he almost hit me. He didn't hit because everyone was there. (INT 18)
... I was physically threatened, the woman came and I was behind the table and she said "ifyou don't answer, if you don't answer, I'll hit you" physically threatened me. (INT 17)

... and then she didn't like it and started offending, she started calling me "nigga", especially my other co-worker, saying that "niggas are like that, they are Antique Farm Equipment" that we had to look for another place to work and said a lot of things... (INT 1)

Interviews showed that situations of violence are common and recurrent, and often the same professional was the victim of more than one type of workplace violence, which was found in $33.9 \%(n=25)$ as represented in Figure 2.

Figure 3 shows the distribution of episodes of workplace violence (considering the total of situations) according to the perpetrators.

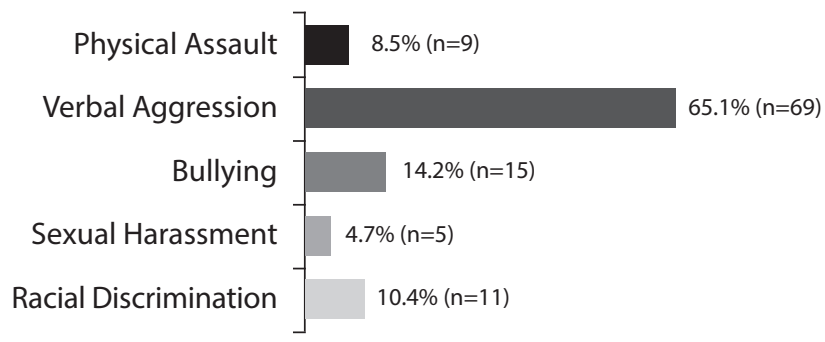

Figure 1- Distribution of occurrences of workplace violence $(n=109)$ by type, Porto Alegre, Rio Grande do Sul, 2019

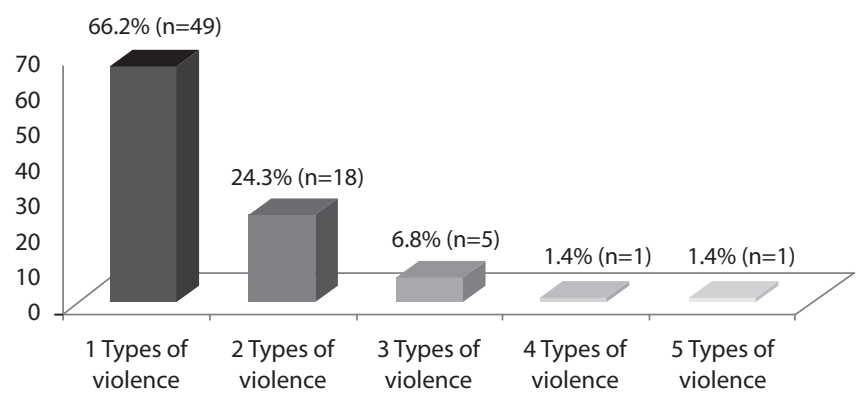

Figure 2 - Percentage of workers exposed to different types of workplace violence $(n=74)$, Porto Alegre, Rio Grande do Sul, 2019

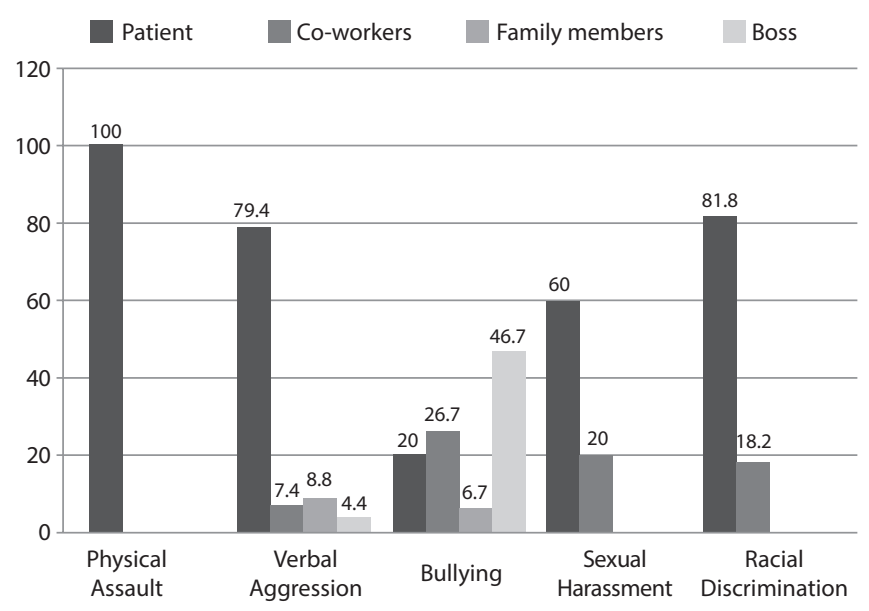

Figure 3 - Distribution of types of workplace violence $(n=109)$ according to perpetrators. Porto Alegre, Rio Grande do Sul, 2019 
Regarding the aggressions perpetrated by co-workers, in the case of verbal aggressions, $20 \%$ were by medical professional, $60 \%$ by $\mathrm{CHAs}$ and $20 \%$ by professional of another category. Bullying was practiced $25 \%$ of the time by physicians and $\mathrm{CHAs}$, and $50 \%$ by nursing staff. Of the professionals who reported being sexually harassed or racially discriminated, when mentioned this practice by co-workers, was perpetrated by CHAs (100\%).

Qualitative data also brought elements to this result, revealing threats from users, but also situations involving the boss and co-workers:

[...] I have already been threatened [by users] saying they were going to stab me, they were going to shoot me [...] then she threatened saying that she would pick me up on the street, that she knew what my car was, to be careful on the street [...] (INT 18)

[...] the physician thought he was getting too patient when he wasn't. And he put a sheet between me and the patient while I was still talking, disrespecting me, offending me [...] (INT 12)

They [bosses] they did everything they could to put us against our $\mathrm{co}=$ workers [...] she [coordinator] used to nag us, she was really rude $[. .$.$] (INT 5)$

The following data presents the reactions, measures and consequences of what happened.

The reactions arising from the episodes of violence suffered were mentioned in participants' reports and composed the thematic axis "reactions", in which the following excerpts were gathered:

Due to these situations, you kind of get ready, but can't come [to work], [...] at the time, I decided to shut up. (INT 6)

In addition, it is noted that replicating violence to the perpetrator may also be a victim response, and therefore an implication on the quality of care.

Table 1 - Distribution of reactions, measures, supervisor's help and consequences for the offender according to the types of violence, Porto Alegre, Rio Grande do Sul, 2019

\begin{tabular}{|c|c|c|c|c|c|}
\hline Variables & $\begin{array}{l}\text { Physical } \\
\text { Assault }\end{array}$ & $\begin{array}{c}\text { Verbal } \\
\text { Aggression }\end{array}$ & Bullying & $\begin{array}{c}\text { Sexual } \\
\text { Harassment }\end{array}$ & $\begin{array}{c}\text { Racial } \\
\text { Disc. }\end{array}$ \\
\hline \multicolumn{6}{|l|}{ Reactions } \\
\hline No reaction & $1(11.1)$ & $10(14.5)$ & $1(6.7)$ & $1(20)$ & $1(9.1)$ \\
\hline Tried to pretend nothing happened & - & $16(23.2)$ & $3(20)$ & $3(60)$ & $4(36.4)$ \\
\hline Asked the person to stop & $3(33.3)$ & $20(29)$ & $4(26.7)$ & $1(20)$ & $1(9.1)$ \\
\hline Tried to physically defend himself & $3(33.3)$ & $1(1.4)$ & - & - & - \\
\hline Told to friends/family & $1(11.1)$ & $15(21.7)$ & $5(33.3)$ & $1(20)$ & $6(54.5)$ \\
\hline Sought advice & $2(22.2)$ & $9(13)$ & $4(26.7)$ & - & $1(9.1)$ \\
\hline Told a co-worker & $3(33.3)$ & $37(53.6)$ & $9(60)$ & $4(80)$ & $6(54.5)$ \\
\hline Reported to a boss & $5(55.6)$ & $39(56.5)$ & $8(53.3)$ & $1(20)$ & $5(45.5)$ \\
\hline Requested transfer & $1(11.1)$ & $1(1.4)$ & - & - & - \\
\hline Registered the event & $6(66.7)$ & $12(17.4)$ & $2(13.3)$ & - & $3(27.3)$ \\
\hline Other & $1(11.1)$ & $15(21.7)$ & $5(33.3)$ & - & $2(18.2)$ \\
\hline \multicolumn{6}{|l|}{ Measures } \\
\hline Yes & $4(44.4)$ & $19(27.5)$ & $6(40)$ & $1(20)$ & $4(36.4)$ \\
\hline No & $5(55.6)$ & $50(72.5)$ & $9(60)$ & $4(80)$ & $7(63.6)$ \\
\hline \multicolumn{6}{|l|}{ Consequences for the ofender } \\
\hline None & $4(44.4)$ & $48(69.6)$ & $12(80)$ & $4(80)$ & $8(72.7)$ \\
\hline Verbal Warning & $1(11.1)$ & $12(17.6)$ & $2(13.3)$ & $1(20)$ & - \\
\hline Interrupted treatment/sector transfer & $2(22.2)$ & $2(2.9)$ & $1(6.7)$ & - & $1(9.1)$ \\
\hline Report at police station & $3(33.3)$ & $5(7.4)$ & - & - & $2(18.2)$ \\
\hline
\end{tabular}

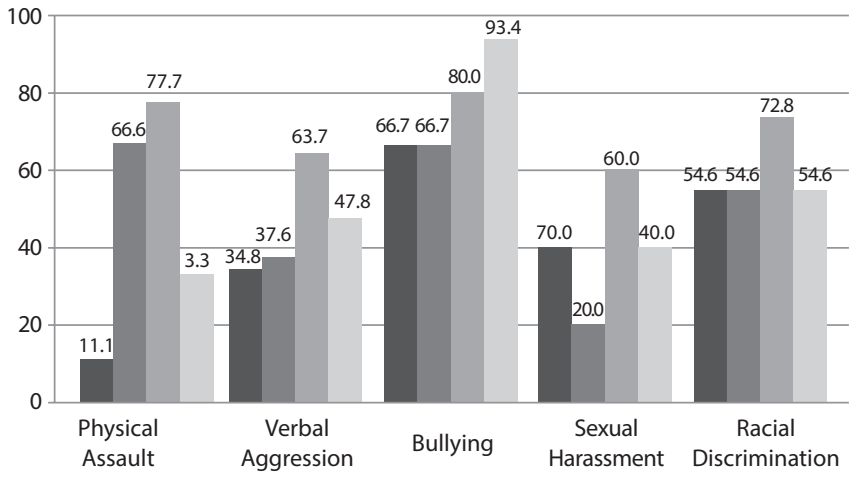

Having repeatitive and disturbing memories, thoughts or images of aggression Avoiding thoughts or speaking on aggression or avoiding feelings realted do it Staying super alert, vigilant, aware or constantly tense

Feeling that activities are now painful

Figure 4 - Moderate to extremely severe distribution of problems experienced by workers exposed to workplace violence $(n=74)$, Porto Alegre, Rio Grande do Sul, 2019

[...] if I have her at the ticket counter and she arrives and I have to meet her, but honestly I serve her like she doesn't exist. And I say neither good morning nor good afternoon. For her, if I'm at the window, she'll get a medication, I'll ask her what she wants and give it. For me, she doesn't exist. (INT 1)

In addition to this aspect, it should be noted that workers end up harming their health from exposure to workplace violence, as shown in Figure 4.

Reports also showed that these situations can have consequences after an event:

I got home shook, I arrived at the unit shook, I'm still shook today [...] I spent the night sleepless, I couldn't eat that night [...] (INT 2)

[...] I had a gastritis, I didn't sleep well anymore [...] I took one fluoxetine a day, I started taking three fluoxetines, because it rocked my relationship with my family, shook my relationship here [...] (INT 5)

[...] isolation, both of greeting people and people not greeting you, not understanding what was really going on, got very boring, imagine being called attention [in front of co-workers] [...] / did a follow-up, I asked the physician to refer me to the worker's referral center. (INT 6)

It was also possible to verify that the work performance started to have repercussions related to behavior change after the episodes of violence, which can be seen in the following excerpts:

[...] it's that thing, I was vigilant, you know? [...] anxiety crisis, even when I go out I look sideways [...] (INT 10)

[...] you are always policing yourself, thinking that something will happen again where you will be disrespected, you will be harassed, it is very exhausting. (INT 12) 
I got a little more agitated, I was afraid to go home, we always get a little alert. [...] it's such an intense situation that you don't stop thinking about it the whole time. (INT 13)

Interviews brought to light, in the subcategory already mentioned, the implications of violence for absenteeism and the desire to quit work.

[...] /'ve been thinking of quitting the service because of that [...] (INT 2)

I had to ask a professional for help because I went on vacation and no longer wanted to go back [...] it makes you want to go to your closet, pick up your things and not look back [...] (INT 9)

I had absences and absences [...] I went through situations like not wanting to come to work even [...] more than once I thought of resigning [...] (INT 6)

[...] I no longer wanted to come to work. Entered in here it felt like the world was carrying on my back [...] (INT 5)

[...] the person cannot concentrate properly [...] the situation of violence that my co-worker suffered and is still suffering, that made him quit work [...] (INT 16)

On the other hand, speeches also evidenced a strong naturalization, which was grouped as "trivialization of situations":

[...] the issues of violence are not that they go unnoticed, but they are being softened because it is all the time. (INT 6)

[...] I take it well. My co-worker asked "do you want to go there and make a report?" And I said "no, there is no need to" [...] I see [violence] as normal. (INT 8)

[...] there are situations you get used to [...] because it is routine, a curse, a verbal aggression, it is routine, you will continue to work and pretend it did not happen [...] (INT 10)

Although sometimes denied, explicit and implicit repercussions of workplace violence at FHU were found on workers' health.

\section{DISCUSSION}

Corroborating the findings of this study, research has shown that psychological violence is more recurrent at $\mathrm{PHC}$ services and, in most cases, professionals are victims of more than one episode of violence in the last year ${ }^{(5,11-13,15,21-23)}$. A Brazilian study found that verbal aggression was the type of violence that most affected workers in health sectors, especially nursing assistants/ technicians (28\%) and physicians (23.9\%) $)^{(19)}$.

A study conducted in Murcia, Spain, revealed an annual prevalence of $90.2 \%$ of acts of psychological violence against workers and $17.3 \%$ of physical assault in the same period ${ }^{(22)}$. A study conducted in Serbia showed that $52.6 \%$ of participants were exposed to workplace violence, and of these, $18.3 \%$ were physical assault ${ }^{(13)}$. A meta-analysis that included 47 studies on health workplace violence, with a total of 81,771 professionals, showed a prevalence of $13.7 \%$ for physical assault; $50.8 \%$ for psychological violence; $61.2 \%$ for verbal abuse; $39.4 \%$ for threats; and $6.3 \%$ for sexual harassment ${ }^{(7)}$.
In Saudi Arabia, a study conducted with 270 PHC professionals showed that $45.6 \%$ of the sample suffered some type of workplace violence in the 12 months prior to the survey. Of these, $6.5 \%$ represented physical assault and $99.2 \%$ psychological violence. Most (79.7\%) of those who experienced violence experienced a single type of violence, while $20.3 \%$ experienced more than one type ${ }^{(11)}$.

In a Brazilian research ${ }^{(15)}$, it was evidenced that $44.9 \%$ reported verbal aggression in the form of insults, being $24.8 \%$ threats. Physical assaults covered $2.3 \%$ and $29.5 \%$ of participants who reported having witnessed episodes of workplace violence. In addition, almost 30\% reported having suffered two or more types of violence. Research carried out in a public hospital service, in the same city of the present study, found that among the victims, $15.2 \%$ suffered physical assault. Regarding psychological violence, $48.7 \%$ of the aggressions were verbal, $24.9 \%$ of the workers suffered bullying, $8.7 \%$ of the cases were racial discrimination and $2.5 \%$ of sexual harassment ${ }^{(17)}$.

Considering the findings of the present study that deal with the way aggressions are manifested, research pointed out that these are user behaviors that doubt professional decisions (34.9\%) and anger over the delay in care $(32.1 \%)$, or acts represented by pushing or squeezing (5.3\%) and damage to the physical environment $(8.1 \%)^{(22)}$. In primary services in Moscow, aggression against physicians is described due to user discontent with referrals and prescriptions for subsidized drugs ${ }^{(24)}$. In an analysis of the indicators of professional exhaustion in $\mathrm{PHC}$, a literature review pointed to the issue of workplace violence ${ }^{(25)}$.

Regarding offenders, users/patients have been cited in previous studies as the main perpetrators of violence against health professionals ${ }^{(17-18,22-24)}$. In a survey conducted in Chile, verbal abuse is primarily perpetrated by patients, their families and the general public (80\%), while most perpetrators of bullying are staff members $(30.8 \%)^{(23)}$.

Given the findings that reported the report to co-workers and bosses as the main reactions of workers exposed to violence, we consider the need for social support to victims, who do not usually register the event. This result can be complemented by the naturalization and trivialization expressed in the interviews, which becomes an important aggravating factor for the phenomenon.

About the few measures and consequences for the offender, identified in the present study, there are in the literature notes of underreporting ${ }^{(25)}$. These notes reveal the lack of measures to contain the recurrence of aggressions and the increase of a culture intolerant to violence. In a survey conducted in southern Brazil, $73.8 \%$ of participants reported the violence suffered only to the supervisor. As a result of the reports, they mentioned that no action was taken on events in $57.3 \%$ of the episodes; $7.1 \%$ of victims requested transfer; the same percentage was attributed to verbal warnings to the perpetrator, to his apology, and to cases of depression and post-medication use ${ }^{(24)}$.

In view of the findings on the problems experienced by professionals after the episode of violence, it was found that these are discomforts that affect the well-being of workers and may compromise aspects of their health, as well as their performance. Another survey pointed out that among professionals who 
reported psychological violence (79\%), 32\% had flashbacks, $24 \%$ developed prevention strategies, $64 \%$ became more vigilant and $22 \%$ considered that all their activities were costly ${ }^{(26)}$.

Another study reports that at the moment of aggression, feelings arise, such as embarrassment, sadness, injustice and insecurity ${ }^{(25)}$. In the case of professionals who suffer more from bullying, less is their job satisfaction ${ }^{(27)}$. A Palestinian study found that exposure to workplace violence was associated with higher occurrence of psychosomatic symptoms ${ }^{(28)}$.

In the present study, the desire to change jobs was also present in participants' statements, which shows the implications for workers' health and the quality of the service offered. In a Chinese study, workplace violence was positively associated with turnover intent, highlighting organizational support as an important mediator between workplace violence and its impact on workers' health and intention to quit work ${ }^{(29)}$. The association between exposure to workplace violence and turnover intent was also found in another survey of Chinese PHC physicians ${ }^{(30)}$.

\section{Study limitations}

This study presents as a limitation the impossibility of having fully addressed the workers of the selected FHU. Observing the work process would also aggregate findings for the research.

\section{Contributions to nursing and health}

Contributions to the area of health, nursing and especially to the field of studies and practices in occupational health derive from the phenomenon visibility of workplace violence at PHC. Workplace violence has been shown to have negative effects on the worker and on the quality of care. The findings show circumstances of high vulnerability that lead to question the real ability to be offered care fostered by dialogue, bonding and humanization, as predicted for the care model in question.

\section{CONCLUSION}

Verbal aggression at FHU's workplace was the most prevalent type of violence $(65.1 \%)$, followed by bullying (14.2\%), racial discrimination (10.4\%), physical assault (8.5\%) and sexual harassment (4.7\%). The qualitative findings complement that, although verbal aggression is prominent, the manifestations are followed by threats of physical attack, which generates fear and distress to workers. $33.9 \%$ of professionals who suffered violence were exposed to more than one type, and the patients were the main perpetrators ( $100 \%$ of physical assault, $81.8 \%$ of racial discrimination, $79.4 \%$ of verbal aggression and $60 \%$ harassment), except for bullying, which had the main responsibility (46.7\%).

Telling a co-worker and reporting to the boss were the victims' main reactions, with perceptions of no action being taken on the incident, as well as consequences for the perpetrator. Remaining overly alert and invariably tense was the most prevalent problem, with percentages ranging from 60 to $80 \%$ of responses depending on the type of violence. Bullying differed, mainly reflecting feelings that activities became more painful (93.4\%). Reports that workers were emotionally and physically shaken, experiencing desires for isolation, withdrawal and job abandonment, qualified these results. Impacts on workers and care were found, although some speeches reveal problem trivialization.

Given the above, investments in FHU workers' health and safety are considered urgent. These cover aspects of structural origin, such as increased working conditions to offer services that more fully meet the demands brought by users, as well as investments in standardized systems for detection and prevention of situations of violence, in view of the vulnerability of workers. The quality of care provided as well as compliance with PHC principles require greater protection for workers' health. They are under penalty of becoming unmotivated, frightened, wishing to quit or withdraw from work, or properly damaged by exposure to workplace violence.

\section{REFERENCES}

1. Maissiat GS, Lautert L, Dal Pai D, Tavares JP. Work context, job satisfaction and suffering in primary health care. Rev Gaúcha Enferm. 2015;36(2):42-9. doi: 10.1590/1983-1447.2015.02.51128

2. Andrade RS, Caldas LBSN, Falcão MLP, Goes PSA. Processo de trabalho em unidade de saúde da família e a educação permanente. Trab Educ Saúde. 2016;14(2):505-21. doi: 10.1590/1981-7746-sip00108

3. Amorim ACCLA, Assis MMA, Santos AM. Vínculo e responsabilização como dispositivos para produção do cuidado na estratégia saúde da família. Rev Baiana Saúde Pública. 2014;38(3):539-54. doi: 10.5327/Z0100-0233-2014380300004

4. Costa JP, Jorge MSB, Vasconcelos MGF, Paula ML, Bezerra IC. Resolubilidade do cuidado na atenção primária: articulação multiprofissional e rede de serviços. Saúde Debate. 2014;38(103):733-43. doi: 10.5935/0103-1104.20140067

5. Rincón-del Toro T, Villanueva-Guerra A, Rodríguez-Barrientos R, Polentinos-Castro E, Torijano-Castillo MJ, de Castro-Monteiro E, et al. Agresiones sufridas por las personas que trabajan en atención primaria de la Comunidad de Madrid, 2011-2012[Internet]. Rev Esp Salud Publica. 2016 [cited 2019 Jan 03];90:1-12. Available from: http://scielo.isciii.es/pdf/resp/v90/1135-5727-resp-90-e40020.pdf

6. Carvalho BG, Peduzzi M, Ayres JRCM. Concepções e tipologia de conflitos entre trabalhadores e gerentes no contexto da atenção básica no Sistema Único de Saúde (SUS). Cad Saúde Pública. 2014;30(7):1453-62. doi: 10.1590/0102-311X00134613

7. Lu L, Dong M, Wang SB, Zhang L, Ng CH, Ungvari GS, Li J, Xiang YT. Prevalence of workplace violence against health-care professionals in China: a comprehensive meta-analysis of observational surveys. Trauma, Viol abuso. 2018. doi: 10.1177/1524838018774429

8. Edward KL, Stephenson J, Ousey K, Lui S, Warclow P, Giandinoto JA. A systematic review and meta-analysis of factors that relate to aggression perpetrated against nurses by patients/relatives or staff. J Clin Nurs. 2015;25(3-4):289-99. doi: 10.1111/jocn.13019 
9. Organización Internacional del Trabajo (OIT); Organización Mundial de la Salud (OMS); Consejo Internacional de Enfermeras (CIE); Internacional de Servicios Públicos (ISP). Directrices marco para afrontar la violencia laboral em el sector de la salud [Internet]. Ginebra; $33 \mathrm{p}$. 2002 [cited 2019 Jan 16]. Available from: http://apps.who.int/iris/bitstream/handle/10665/44072/9223134463_spa.pdf;jsessionid=0165A2E 42850D4346E793D9BD6B8DB9B? sequence=1

10. Palacios M. Relatório preliminar de pesquisa. Violência no trabalho no setor saúde: Rio de Janeiro [Internet]. Universidade Federal do Rio de Janeiro: 2002 [cited $2019 \mathrm{Jan}$ 16]. Available from: http://www.assediomoral.org/IMG/pdf/pesquisa_sobre_Violencia_no_trabalho_Universidade_Federal_RJ.pdf

11. El-Gilany AH, El-Wehady A, Amr M. Violence against primary health care workers in Al-Hassa, Saudi Arabia. J Interpers Violence. 2010;25(4):716-34. doi: 10.1177/0886260509334395

12. Gascon S, Leiter MP, Andrés E, Santed MA, Pereira JP, Cunha MJ, et al. The role of aggression suf-fered by health care workers as predictors of burnout. J Clin Nurs. 2013;22(21-22):3120-9. doi: 10.1111/j.1365-2702.2012.04255.x

13. Fisekovic MB, Trajkovic GZ, Bjegovic-Mikanovic VM, Terzic-Supic ZJ. Does workplace violence exist in primary health care? evidence from Serbia. Eur J Public Health. 2015;25(4):693-8. doi: 10.1093/eurpub/cku247

14. Batista CB, Campos AS, Reis JC, Schall VT. Violência no trabalho em saúde: análise em unidades básicas de saúde de Belo Horizonte, Minas Gerais. Trab Educ Saúde. 2011;9(2):295-317. doi: 10.1590/S1981-77462011000200008

15. Silva AT, Peres MF, Lopes CS, Schraiber LB, Susser E, Menezes PR. Violence at work and depressives symptoms in primary health care teams: a cross-sectional study in Brazil. Soc Psychiatry Psychiatr Epidemiol. 2015;50(9):1347-55. doi: 10.1007/s00127-015-1039-9

16. Di Martino V. Workplace violence in the health sector: country case studies (Brazil, Bulgarian, Lebanon, Portugal, South África, Thailand, and an additional Australian study) [Internet]. 2002 [cited 2019 Jan 16]. Available from: http://www.who.int/violence_injury_prevention/injury/ en/WVsynthesisreport.pdf

17. Dal Pai D, Sturbelle ICS, Santos C, Tavares JP, Lautert L. Physical and psychological violence in the workplace of health care professionals. Texto Contexto Enferm. 2018;27(1):1-10. doi: 10.1590/0104-07072018002420016

18. Dal Pai D, Lautert L, Souza SBC, Marziale MHP, Tavares JP. Violence, burnout and minor psychiatric disorders in hospital work. Rev Esc Enferm USP. 2015;49(3):460-68. doi: 10.1590/S0080-623420150000300014

19. Silva IV, Aquino EML, Pinto ICM. Violência no trabalho em saúde: a experiência de servidores estaduais da saúde no Estado da Bahia, Brasil. Cad Saúde Pública. 2014;30(10):2112-22. doi: 10.1590/0102-311X00146713

20. Minayo MCS. (org). Pesquisa Social. Teoria, método e criatividade. Petrópolis: Vozes; 2011. 108p.

21. Lindner T, Joachim R, Bieberstein S, Schiffer H, Möckel M, Searle J. Aggressives und herausforderndes Verhalten gegenüber dem Klinikpersonal Ergebnisse einer Mitarbeiterbefragung in den Notfallbereichen der Charité - Universitäts medizin Berlin. Notfall Rettungsmed. 2015;18(3):195200. doi: 10.1007/s10049-015-1982-8

22. Ruiz-Hernández JA, López-García C, Llor-Esteban B, Galián-Muñoz I, Benavente-Reche AP. Evaluation of the users violence in primary health care: adaptation of an instrument. Int J Clin Health Psychol. 2016;16(3):295-305. doi: 10.1016/jijchp.2016.06.001

23. Campo VR, Klijn TP. Verbal abuse and mobbing in pre-hospital care services in Chile. Rev Latino-Am Enferm. 2017;25:e2956. doi: $10.1590 / 1518-8345.2073 .2956$

24. Gatsura O, Zimina E, Deriushkin V, Gatsura S. Workplace violence against primary care doctors and specialty physicians in Moscow polyclinics: Vladimir Deriushkin. European J Public Health. 2018. 28(4). doi: 10.1093/eurpub/cky218.280

25. Garcia GPA, Marziale MHP. Indicators of burnout in Primary Health Care workers. Rev Bras Enferm. 2018;71(5):2334-42. doi: 10.1590/0034-7167-2017-0530

26. Gignon M, Verheye JC, Manaouil C, Ammirati C, Turban-Castel E, Ganry O. Fighting violence against health workers: a way to improve quality of care? Workplace Health Saf. 2014;62(6):220-2. doi: 10.3928/21650799-20140514-02

27. Jaradat Y, Nielsen MB, Kristensen P, Nijem K, Bjertness E, Stigum H, et al. Workplace aggression, psychological distress, and job satisfaction among Palestinian nurses: a cross-sectional study. Appl Nurs Res. 2016; 32:190-198. doi: 10.1016/j.apnr.2016.07.014

28. Jaradat $Y$, Nielsen MB, Bast-Pettersen R. Psychosomatic symptoms among Palestinian nurses exposed to workplace aggression. Am J Ind Med. 2018;61:533-37. doi: 10.1002/ajim.22851

29. Liu W, Zhao S, Shi L, Zhang Z, Li X, Li L, et al. Workplace violence, job satisfaction, burnout, perceived organisational support and their effects on turnover intention among Chinese nurses in tertiary hospitals: a cross-sectional study. BMJ Open. 2018;8:e019525. doi:10.1136/ bmjopen-2017-019525

30. Gan Y, Gong Y, Chen Y, Cao S, Li L, Zhou Y, et al. Turnover intention and related factors among general practitioners in Hubei, China: a crosssectional study. BMC Fam Pract. 2018;19(1):74. doi: https://doi.org/10.1186/s12875-018-0752-3 